\title{
Functional green roofs: importance of plant choice in maximising summertime environmental cooling and substrate insulation potential
}

\section{Article}

Accepted Version

Creative Commons: Attribution-Noncommercial-No Derivative Works 4.0

Vaz Monteiro, M., Blanusa, T., Verhoef, A., Richardson, M., Hadley, P. and Cameron, R. W. F. (2017) Functional green roofs: importance of plant choice in maximising summertime environmental cooling and substrate insulation potential. Energy and Buildings, 141. pp. 56-68. ISSN 0378-7788 doi: https://doi.org/10.1016/j.enbuild.2017.02.011 Available at https://centaur.reading.ac.uk/69025/

It is advisable to refer to the publisher's version if you intend to cite from the work. See Guidance on citing.

To link to this article DOI: http://dx.doi.org/10.1016/j.enbuild.2017.02.011

Publisher: Elsevier

All outputs in CentAUR are protected by Intellectual Property Rights law, including copyright law. Copyright and IPR is retained by the creators or other copyright holders. Terms and conditions for use of this material are defined in the End User Agreement. 


\section{www.reading.ac.uk/centaur}

\section{CentAUR}

Central Archive at the University of Reading

Reading's research outputs online 
3 Functional green roofs: Importance of plant choice in maximising

\section{summertime environmental cooling} and substrate insulation potential

M. Vaz Monteiro ${ }^{1 \#}$, T. Blanuša ${ }^{1,2, *}$, A. Verhoef ${ }^{3}$, M. Richardson ${ }^{1}$, P. Hadley ${ }^{1}$ and R.W.F. Cameron ${ }^{4}$ 8

$9 \quad{ }^{1}$ School of Agriculture, Policy and Development, University of Reading, RG6 6AS, UK

$10 \quad{ }^{2}$ Royal Horticultural Society, Plant Sciences Department, Garden Wisley, Woking GU23 6QB, UK

$11{ }^{3}$ Department of Geography and Environmental Science, School of Archaeology, Geography and

12 Environmental Science; University of Reading, Whiteknights, RG6 6AB, UK

$13{ }^{4}$ Department of Landscape, University of Sheffield, S10 2TN, UK

14

15 *author for correspondence: tijanablanusa@rhs.org.uk

16 \#Current address: Urban Forest Research Group, Centre for Sustainable Forestry and Climate Change,

17 Forest Research, Alice Holt Lodge, Farnham, GU10 4LH, UK

18 


\section{Abstract}

20 Green roof plants can reduce local air temperatures and heat load to a building in the summer, improving thermal comfort of residents. Little is known, however, about how different plants compare in their potential to provide these two ecosystem services. Consequently, this study investigated whether some plants can offer more potential summertime environmental cooling and substrate insulation than others. Over two summers (2012/2013), canopies of two succulent and four broadleaved plant genotypes, with contrasting plant traits, were monitored alongside bare substrate in Reading, UK. Plants were studied outdoors within small plots $(1.5 \times 1.5$ x $0.1 \mathrm{~m})$. Continuous monitoring took place during warm days and nights and included variables (leaf surface temperatures) and fluxes (long-wave radiation, sensible heat flux and transpiration) that are indicative of cooling potential. The strength of substrate insulation was estimated by comparing the ground heat flux below the canopies to that of the bare substrate. Plant traits (leaf colour or thickness), structural parameters (height and leaf area index, LAI), radiative properties (albedo and emissivity), and stomatal conductance were also measured to help explain the differences in cooling potential among the species. Non-succulent canopies, in particular light-coloured ones, with high leaf stomatal conductance and high LAI provided maximum potential for substrate insulation and environmental cooling in hot periods, particularly compared to bare substrate and thick-leaved succulents. These results suggest that succulent plants are not best suited to provide significant summertime environmental cooling and substrate insulation and that others (e.g. Salvia and Stachys) might be preferable where the delivery of these benefits is a priority. Our findings highlight that, in addition to survival, aesthetics and cost, the plants' ability to deliver a range of ecosystem services should be considered in the plant selection/green roof planning process.

\section{Keywords}

43 Green roofs; Plant traits; Salvia; Sedum; Surface energy balance 


\section{$44 \quad$ Highlights}

- Plant canopy traits strongly affect cooling and insulation by roof substrates.

46 - Salvia and Stachys potentially provide superior summer cooling/substrate insulation.

47 - Thick-leaved succulents do not offer more summer cooling/insulation than bare soil.

48 - Dark-leaved plants offered good substrate insulation, but not aerial cooling potential. 


\section{Introduction}

51 Urban landscapes are typically warmer than adjacent rural areas [1]. This phenomenon, (the urban heat island, UHI), is partly due to anthropogenic activities which generate heat that becomes trapped within the urban fabric. It is also due to a widespread use of impervious materials, which alter the thermal and radiative properties of the land surface, significantly influencing the surface energy balance [2,3]. In urbanised areas, latent heat flux (i.e. evapotranspiration) is thus reduced compared to more rural, vegetated areas, while heat storage and the resulting re-emission of heat as long-wave radiation or sensible heat are increased. The heat absorbed, stored and re-released as long-wave radiation by the urban fabric to the atmosphere can also be intercepted by air pollutants and redirected back to the urban environment, contributing to further warming [3].

The UHI generally has a negative impact on human thermal comfort and health, and this impact is predicted to increase due to a warming climate. For example, by the $2080 \mathrm{~s}$, mean summertime maximum air temperatures in southern England are estimated to rise by an average of $5.4^{\circ} \mathrm{C}$, compared to 1961-1990 [4]. Heat wave events, which amplify human mortality rates, are also expected to increase in intensity, duration and frequency [5]. Residents in urban areas will be particularly susceptible to such events, owing to the already enhanced temperatures associated with the UHI effect.

Plants in cities have an important role in reducing local summertime air temperatures and can mitigate local UHI [6-9]. However, the area available in highly urbanised cities for green infrastructure expansion is scarce. Roofs can occupy around $30 \%$ of the horizontal surface within a city [10], making them prime spaces to be vegetated. In addition to being able to reduce local air temperatures [11], plants on roofs (i.e. green roofs) can further reduce the energy load to the buildings during the day in summer, thereby leading to a reduced reliance on artificial air conditioning, thus saving energy $[12,13]$. 
Such ecosystem services (i.e. both in terms of summertime air temperature regulation and the plants' ability to reduce the summertime conductive heat load, thus increasing the insulation of the rooftop) can be provided by a variety of mechanisms. Plants hold, and can subsequently release, relatively large volumes of water. The vapourisation of liquid water consumes about $2450 \mathrm{~J}$ per $\mathrm{g}$ of water [14]. This latent energy is retained in the water molecules that exit through the leaf stomata [15], allowing radiation absorbed by well-watered plants to dissipate without an increase in air temperature within the immediate environment. Plants on roofs may also absorb less heat than bare roof surfaces [12], due to higher reflectance, at least compared to dark surface materials such as bitumen or slate. Additionally, plants in urban areas partially absorb the long-wave energy re-emitted by the adjacent built surfaces [16] as well as shade a built surface [17]. Thus, when placed on roofs they can reduce the radiation received by the roof surface. A model simulating the thermal behaviour of green roofs when several parameters, including LAI, were manipulated, found that an increase in LAI from 2 to 5 led to a decrease of almost $250 \mathrm{~W} \mathrm{~m}^{-2}$ in solar radiation transmitted to the roof surface [18]. When combined, these features lead to green roofs (consisting of the canopy and the below-canopy rooftop) being considerably cooler in the summer than their non-green counterparts. This will result in a decrease in the heat conducted to the inner parts of the building, but also reduces the release of sensible heat and long-wave radiation by the roof, thereby decreasing the extent of warming to the wider urban environment.

While plants differ in their surface temperature when compared to inert roof materials, variations in leaf characteristics and canopy structure, substrate factors and physiological traits can vary the thermal properties of canopies associated with different species. Leaf temperature is strongly influenced by substrate moisture content and leaf stomatal conductance $[19,20]$. Morphological traits such as leaf colour, thickness and pubescence also influence leaf temperature [20,21].

Many green roofs are planted with succulents such as Sedum, as they tolerate the dry conditions common on extensive green roofs $[22,23]$. However if sustainable irrigation was possible, other lowgrowing plants with higher water requirements could survive too [24]. More water-demanding plants, if possessing the 'right' traits, could potentially generate greater environmental cooling and substrate 
insulation in the summer than succulents. A previous study within a Mediterranean climate, however, could not justify the use of green roofs (with succulent, grass, perennial or small shrub covering) solely on the basis of beneficial cooling effects, particularly taking into account the water use and associated costs [25]. In contrast though, in climates where natural precipitation is higher and evenly distributed over the seasons, the economic benefits of using more water-demanding plants (in terms of reduced air conditioning, for example) may outweigh costs linked to supplementary irrigation. Despite preliminary evaluations on how different roof plant communities affect the surrounding environment and the thermal performance of a roof [26-29], there is still a lack of knowledge on how key plant traits influence the energy balance of the combined substrate/vegetation layer and the implications for using different plants to provide direct cooling or insulation services.

The main aim of this research was to determine the extent to which plant genotype affects the thermodynamic properties of the substrate-vegetation system during summer. A range of plants potential useful for green roof situations, were evaluated within the context of the UK's temperate maritime climate. This study deliberately does not account for any factors (e.g. roof/building material, roof orientation, building energy efficiency etc.) that may influence the cooling attributes of green roofs per se. Such an experimental set-up would struggle to be comprehensive and would be too complicated from an in-depth monitoring point of view, thereby limiting the amount, and potentially compromising the quality, of the micrometeorological and plant physiological data. To achieve our aim, six genotypes (two succulent and four broad-leaved) with contrasting leaf stomatal conductance rates and variations in leaf colour, pubescence or thickness were selected. Canopies were compared over two summers with regards to their surface temperatures, outgoing long-wave radiation, and their surface energy balance (net radiation and turbulent heat fluxes, as well as substrate heat flux). Additional comparisons were made with bare substrate (i.e. non-vegetated plots), which acted as an experimental control.

Improved understanding of the combined effect of these traits will allow urban planners, architects and green roof professionals to base their future choice of plants not only on genotypes' survival and aesthetical value, but also on their ability to maximise important ecosystem services. 


\section{Materials and Methods}

\subsection{Plant material}

All plants in the experiment were herbaceous/sub-shrub forms (Figure 1) with potential to be integrated in green roofs, particularly if additional irrigation is provided during times of prolonged water deficit. These were (with key leaf characteristics in parenthesis):

- Heuchera 'Obsidian' (non-pubescent, purple)

- Heuchera 'Electra' (non-pubescent, yellow)

- Salvia officinalis 'Berggarten' (pubescent with grey-green hue)

- Stachys byzantina (pubescent with pale grey hue)

- Sempervivum 'Reinhard' (non-pubescent, succulent, light to dark green hue)

- Sedum mix (a mat of Sedum species used as an industry standard; non-pubescent, succulent leaves, light-green hue).

Individual plants were either propagated in-house or acquired from UK nurseries, as plugs or $9 \mathrm{~cm}$ potted plants. Sedum mix was acquired as a green roof mat from a commercial supplier (Q lawns, Hockwold-cum-Wilton, UK). Non-succulent plants were replanted into $2 \mathrm{~L}$ containers to aid further establishment, at least one month before being planted into the experimental plots. [Insert Figure 1]

\subsection{Experimental setup}

Experiments were carried out in the summers of 2012 (24 July to 21 September) and 2013 (15 July to 31 August), on the outdoor experimental grounds at the University of Reading (UK). In 2012, fourteen timber frames were constructed $(1.5 \times 1.5 \times 0.1 \mathrm{~m})$ and positioned $1.1 \mathrm{~m}$ apart. These were placed in an open space at ground level rather than on top of building roofs to minimise any ancillary thermal effects due to building function and infrastructure (parapets, air cooling vents, chimney flues, etc.) and for ease of access. All frames were lined with polyethylene pond liner and filled with a $0.1 \mathrm{~m}$ 
layer of John Innes compost No. 2. Field capacity and permanent wilting point of a similar substrate were respectively measured at 0.32 and $0.07 \mathrm{~g} \mathrm{~g}^{-1}$ [30]; equivalent to 0.42 and $0.09 \mathrm{~m}^{3} \mathrm{~m}^{-3}$ when assuming a substrate bulk density of $1.3 \mathrm{~g} \mathrm{~cm}^{-3}$, an average of values presented for soils and composts with comparable compositions [31,32]. Each treatment was replicated twice, i.e. two 'mono-culture' plots of each genotype. Plant genotypes were randomly allocated to the plots and planted at least 10 days before measurements started, to achieve $100 \%$ of coverage (or in the case of Sempervivum $80 \%$, due to the small size of the plants). The Sedum mix mat was cut to fit the plot with the underneath membrane removed, to ensure direct contact with the substrate.

Two of the frames were left with just bare substrate so that plant canopies could be compared to an unplanted 'control' surface. A layer of bare substrate was used instead of a rigid inert surface, as it has similar hydraulic (i.e. in relation to water retention and transfer) and thermal properties to the substrate layers located below the plant canopies.

In 2013, two additional timber frames were constructed and a new treatment was added. These vacant plots were planted with shorter specimens of Salvia, where shoot tips were pinched out to promote a bushier, lower habit. Consequently, in 2013, Salvias planted in that year were approximately half the height of Salvias planted in 2012; these treatments were used to assess the effect of canopy height on the variables studied.

Plots and surrounding areas were kept weed free, and any emerging flower heads removed from the plants to ensure that only the leaf canopy effect was accounted for (flower heads only accounted for a very small area).

Environmental and temperature measurements, described in Table 1, represent mean values over a 10 minute period (averaged from measurements made every 10 seconds). Sensors (full list in Table 1) were attached to DL2e loggers (Delta-T Devices Ltd., Cambridge, UK) and a DataHog2 logger (Skye Instruments Ltd., Llandrindod Wells, UK), which were covered by well-ventilated white plastic boxes to protect from intense radiation. In addition, incoming long-wave radiation $\left(L_{\mathrm{i}}\right)$ and wind speed $\left(U_{\mathrm{z}},\right)$ at $2 \mathrm{~m}$ from the ground were monitored at the University's meteorological station, located $600 \mathrm{~m}$ from the experimental plots. 
Leaf temperature, $T_{\mathrm{s}}$, was measured using thermocouples (Table 1, Figure 2) attached to the underside of individual leaves mostly with a plastic paper clip [33] thus ensuring the thermocouple was located within the leaf boundary layer (i.e. the air layer in contact with the leaf surface). For succulent and Stachys leaves, which are small or easily broken, thermocouples were attached by threading [34]. In all cases, selected leaves were young, exposed and fully expanded, and located in the upper layer of the canopy. In 2013, plant coverage of yellow Heuchera was reduced to $<50 \%$ due to winter losses, thus one of the thermocouples within each plot with yellow Heuchera was used to measure leaf temperature whilst the other was used to measure substrate temperature.

Thermocouples and thermistors were calibrated at the start of each experimental season in a hot water bath and were measuring within $0.30^{\circ} \mathrm{C}$ of each other.

The instantaneous measurements of plant and substrate parameters/variables carried out over the course of the experiment (i.e. substrate moisture, SMC; leaf stomatal conductance, $g_{s}$; albedo, $\alpha$; spectral reflectance; leaf area index, LAI and canopy height, $h$ ) are described in Table 2 (also see Figure 2). In addition to the discrete measurements (Table 2), SMC was also continuously recorded hourly on four randomly selected plots, with SM200 sensors (Delta-T Devices Ltd., Cambridge, UK). Both the discrete and continuous SMC measurements were used to estimate continuous SMC variations in each treatment, information needed to estimate substrate heat flux and to guide irrigation requirements. Leaf emissivity, $\varepsilon$, which plays an important role in net radiation calculation via the outgoing longwave radiation term, was determined in a laboratory test in 2012. Four leaves from each genotype were evaluated, except for Sempervivum where the shape of its leaves prohibited the measurement. For each leaf, $\varepsilon$ was calculated based on the temperatures extracted from a thermal image, recorded with an infrared imaging camera FLIR i5 (FLIR Systems UK, West Malling, UK) whilst the leaf was floating in a well-stirred water bath [35]. In all cases, $\varepsilon$ was around 0.97. The fact that all leaf emissivities were similar suggests that any differences in $T_{\mathrm{s}}$ between genotypes which we subsequently determined were caused by differences in $\alpha, g_{s}$ and/or leaf traits that affect aerodynamic transfer. 


\subsection{Watering requirements}

209 In both summers, all plots, including the bare ones, were manually irrigated whenever a plot's mean 210 SMC fell below $0.15 \mathrm{~m}^{3} \mathrm{~m}^{-3}$. Water applied was adjusted so that mean SMC after irrigation was around $0.32 \mathrm{~m}^{3} \mathrm{~m}^{-3}$. Salvia received the highest irrigation water quantity in both years and

212 Sempervivum the lowest. The total water received by the canopies in 2013 (quantities given are a

213 combination of both precipitation and supplementary watering) was approximately: $134 \mathrm{~L} / \mathrm{m}^{2}$ for 214 Salvia planted in 2012, $127 \mathrm{~L} / \mathrm{m}^{2}$ for Salvia planted in 2013, $126 \mathrm{~L} / \mathrm{m}^{2}$ for purple Heuchera, $105 \mathrm{~L} / \mathrm{m}^{2}$ 215 for Stachys, $99 \mathrm{~L} / \mathrm{m}^{2}$ for Sedum, $93 \mathrm{~L} / \mathrm{m}^{2}$ for yellow Heuchera (in plots partially covered) and $77 \mathrm{~L} / \mathrm{m}^{2}$ 216 for Sempervivum.

217 When plots were irrigated, the soil around their frame was also irrigated to reduce micro-scale 218 advection typical of small-sized plot design experiments surrounded by soil with different moisture 219 concentrations [36].

\subsection{Calculation of the outgoing long-wave radiation and surface energy balance}

Net radiation, outgoing long-wave radiation and heat fluxes were calculated for every 10 minutes and averaged hourly. Net radiation, $R_{\mathrm{n}}$, was calculated as:

where $S_{\mathrm{i}}$ and $L_{\mathrm{i}}$ are the short-wave and long-wave radiation received by the surface, and $S_{\mathrm{o}}$ and $L_{\mathrm{o}}$ are the short-wave and long-wave radiation reflected and emitted by the surface. At night, $S_{\mathrm{o}}$ was assumed to be $0 \mathrm{~W} \mathrm{~m}^{-2}$.

Continuous daytime $S_{\mathrm{o}}$ values were not available, but representative estimates of albedo, $\alpha$, were obtained (see Table 2) to derive $S_{\mathrm{o}}$. Using these data, between 10:00-16:00 h, $S_{\mathrm{o}}$ was calculated as:

$229 S_{\mathrm{o}}=\alpha S_{\mathrm{i}}$

230 Between 06:00-10:00 $\mathrm{h}$ and 16:00-20:00 $\mathrm{h}, \alpha$ was either assumed to be equal to the mean $\alpha$ values between 10:00-16:00 h (when mean $S_{\mathrm{i}}<200 \mathrm{~W} \mathrm{~m}^{2}$ ), or assumed to increase linearly with a decreasing sun angle (when mean $S_{\mathrm{i}}>200 \mathrm{~W} \mathrm{~m}^{2}$ ) [37]. Based on values presented by Monteith and Szeicz [37], 
233 during sunny periods, maximum $\alpha$ (at 06:00 or 20:00 h) was set to a value that was 0.05 higher than

234 the mean $\alpha$ for the period between 10:00-16:00 $\mathrm{h}$ for canopies, or to 0.03 for bare substrate.

$235 L_{\mathrm{o}}$ was calculated according to Stefan-Boltzmann's law:

$236 L_{\mathrm{o}}=\varepsilon \sigma\left(T_{\mathrm{s}}\right)^{4}+(1-\varepsilon) L_{\mathrm{i}}$,

237 where $\sigma$ is the Stefan-Boltzmann constant. $T_{\mathrm{s}}$, the mean leaf/surface temperature of each plot, was

238 calculated as the mean of temperatures measured by the thermocouples and $\varepsilon$ was assumed to be on

239 average 0.95 for the bare substrate (based on the ranges presented for bare soils by Rubio et al. [38]),

$240 \quad 0.97$ for canopies with LAI $>1$, as measured, and 0.96 for canopies with LAI $<1$.

241 Sensible heat flux, $H$, was calculated as:

242

$H=\rho \mathbf{a} C \mathbf{p} \frac{(T \mathrm{~s}-T \mathrm{a})}{\mathbf{r a}}$

243 where $T_{\mathrm{a}}$ is the air temperature recorded at $2 \mathrm{~m}$ from the ground, $\rho_{\mathrm{a}}$ is the air density, $C_{\mathrm{p}}$ is the air 244 specific heat and $r_{\mathrm{a}}$ is the aerodynamic resistance, calculated as:

$r \mathbf{a}=\frac{\ln \left(\frac{z-d}{z o m}\right) \ln \left(\frac{z-d}{z o h}\right)}{k^{2} U \mathbf{z}}$,

where $z$ is the height of wind and temperature measurements, $d$ is the zero plane displacement height, $z_{\mathrm{om}}$ is the surface roughness length for momentum transfer, $z_{\mathrm{oh}}$ is the surface roughness length for heat and vapour transfer, $k$ is the von Karman's constant $(0.41)$ and $U_{\mathrm{z}}$ is the wind speed. In this equation

249 the effect of atmospheric stability has been neglected as this effect is relatively small.

250 Roughness parameters $d, z_{\mathrm{om}}$ and $z_{\mathrm{oh}}$ were calculated as a function of surface cover height:

$251 d=2 / 3 h$

252

$z_{\mathrm{om}}=0.123 \mathrm{~h}$

$z_{\mathrm{oh}}=0.1 \mathrm{z}_{\mathrm{om}}$

254 The height of bare substrate was set to $0.01 \mathrm{~m}$, leading to a $z_{\text {om }}$ for bare substrate of $0.001 \mathrm{~m}$ [39].

255 Substrate heat flux, $G$, was estimated by Fourier's law:

256

$G=-\lambda \frac{\boldsymbol{\Delta} T}{\boldsymbol{\Delta} Z}$, 
here $\Delta T$ is the substrate temperature difference between two depths (at $0.01 \mathrm{~m}$ and $0.06 \mathrm{~m}$ ) and $\Delta z$ is the distance between those two depths. The substrate thermal conductivity, $\lambda$, was calculated based on the assumed value of substrate bulk density, the quartz content and the estimated continuous SMC, as per Lu et al. [32]. Using Eq. 9 with substrate temperatures measured at $0.01 \mathrm{~m}$ and $0.06 \mathrm{~m}$ means that the heat stored in the first $0.01 \mathrm{~m}$ of substrate was not accounted for. Calculating this storage would require an estimate of heat capacity, $C_{\mathrm{h}}$, but SMC (required to calculate $C_{\mathrm{h}}$ ) in such a thin layer cannot be easily determined. Alternatively one could use substrate temperature at $0 \mathrm{~m}$ (i.e. the substrate surface temperature) to calculate the temperature difference in Eq. 9, but this variable was only measured in uncovered (bare) plots. However, this storage term was assumed to be relatively small, in particular below vegetation. Furthermore, the plots, albeit lined with polyethylene membranes, were not thermally insulated from the ground below them. Thermistors were placed at $0.06 \mathrm{~m}$ from the substrate surface (and $0.04 \mathrm{~m}$ from the membranes) to reduce the influence that the heat flux from the ground below may have had on the calculated $G$. We use $G$ to assess substrate insulation potential of the green roof plant species. We define substrate insulation potential as the reduction in (surface) ground heat flux by vegetation cover compared to bare substrate.

Latent heat flux, $L E$, was calculated as the residual of the energy balance:

With these calculations, any advection and storage of heat in the canopy biomass and within the canopy air that might have occurred were embedded in the $L E$ and $H$ heat fluxes terms.

\subsection{Statistical analysis}

Statistical analysis was performed with GenStat $16^{\text {th }}$ Edition (VSN International Ltd., Hemel Hempstead, UK). Differences in $g_{s}$ within a season were assessed with analysis of variance (ANOVA), on the basis of the least significant difference (LSD; 5\% level). Two contrasting groups of data (i.e. day and night) were selected for the analysis of differences in calculated $T_{\mathrm{s}}, L_{\mathrm{o}}, R_{\mathrm{n}}$ and heat fluxes: i). ten (2012)/nine (2013) rain-free days with $T_{\max }>24^{\circ} \mathrm{C}$ and ii). ten rain-free nights with $T_{\min }$

$282>12^{\circ} \mathrm{C}$. For daytime data, the statistical analysis was only performed over intervals of four hours, when differences between treatments reached their maximum: i.e. between 12:00-16:00 h for $T_{\mathrm{s}}$ and $L_{\mathrm{o}}$ 
or 11:00-15:00 h for $R_{\mathrm{n}}$ and heat fluxes. For the night periods, differences were statistically analysed between 20:00-24:00 $\mathrm{h}$, when the effect of the UHI is highest [1].

Data from each selected group/period were analysed using residual maximum likelihood (REML) analysis. All p-values presented in this paper were extracted from each REML analysis and an estimated LSD, as per Andrist-Rangel et al. [40], was used to assess treatment differences. As means considered were based on a number of days (and hours within a day), this should have mostly reduced errors associated with the measurements/calculations.

\section{Results}

\subsection{Environmental and substrate moisture content (SMC) conditions}

293 For the period in which data collection coincided in both seasons (24 July to 31 August) mean daily $T_{\max } / T_{\min }$ in 2012 and 2013 were $22.5^{\circ} \mathrm{C} / 12.6^{\circ} \mathrm{C}$ and $23.1^{\circ} \mathrm{C} / 13.2^{\circ} \mathrm{C}$, respectively. Temperatures for the first thirteen days of the experimental season in 2013 were, however, part of heatwave-like weather experienced in the UK in July 2013 (mean daily $T_{\max } / T_{\min }$ for that period were $27.6^{\circ} \mathrm{C} / 15.2^{\circ} \mathrm{C}$ ).

Despite Sempervivum's plots receiving the lowest amount of water, their SMC was generally the highest (as a result of their low transpiration), particularly in 2013, where Sempervivum's SMC was mostly $\geq 0.30 \mathrm{~m}^{3} \mathrm{~m}^{-3}$. For the remaining treatments, mean SMC varied between $0.15-0.32 \mathrm{~m}^{3} \mathrm{~m}^{-3}$, in both years (data not shown).

\subsection{Plant structure}

Of the genotypes tested, Salvia planted in 2012 was the tallest (Table 3) with a high LAI recorded in both years. The specimens of this species planted in 2013 were shorter, but also had relatively high LAI values. Sempervivum and Sedum had the shortest stature with relatively low LAI, although the LAI of Sempervivum increased between the two years (Table 3). In contrast, both Stachys and yellow Heuchera plots had lower LAI in the second year compared to the first. In plots with yellow Heuchera, the LAI reduction between 2012 and 2013 was particularly dramatic; this was due to many plants perishing during winter. By 2013, the yellow Heuchera plots had the lowest LAI (Table 3). 
310 The $\alpha$ of most plant plots remained unaltered throughout the two-year period (Table 3). There was, 311 however, a marked reduction in $\alpha$ of yellow Heuchera plots, with its 2012 value of 0.27 falling to 0.14 in 2013. Again, this is the result of the severe reduction in plant cover, which left bare substrate, with its lower $\alpha$, in particular when wet, exposed. The $\alpha$ of Sempervivum plots was also slightly altered

314 from 2012 to 2013, increasing from 0.14 to 0.17 (Table 3), as in 2013 Sempervivum plants were covering the substrate fully. In uncovered plots, the average $\alpha$ was lower in 2012 than in 2013 (Table 3), probably due to small SMC differences during the days when $\alpha$ was measured. An evaluation of spectral reflectance (in the short-wave spectrum) in 2012 showed that the yellow Heuchera plants reflected more radiation than other canopies in the visible wavelengths whilst the purple Heuchera plants reflected less (400-700 nm; Figure 3). At longer wavelengths (700 to 1250 $\mathrm{nm}$; the near infrared region), reflectance was generally greater; differences between genotypes were more spread in these wavelengths than in the visible spectrum, where only Heucheras plants had different reflectance (Figure 3). Bare substrate on average reflected less radiation than the plants throughout most of the short-wave spectrum; however, in the visible part of the spectrum, bare substrate reflected more than purple Heuchera plants. [Insert Table 3 and Figure 3]

\subsection{Leaf stomatal conductance $\left(g_{s}\right)$}

Salvia had the highest mean $g_{s}$ values, with the new Salvia treatment planted in 2013 having a similar mean $g_{s}$ to that of Salvia planted in 2012. Sedum had the lowest $g_{s}(\mathrm{p}<0.001)$, with mean values differing by $249 \mathrm{mmol} \mathrm{m}^{-2} \mathrm{~s}^{-1}$ in 2012 and $185 \mathrm{mmol} \mathrm{m}^{-2} \mathrm{~s}^{-1}$ in 2013 from those of Salvia planted in 2012 (Figure 4). Due to time restrictions, the number of $g_{s}$ measurements executed in 2013 was substantially lower than in 2012, this might have contributed (along with differences in the stages of plant maturity or differences in the environmental conditions at the time of measuring) to most treatments having slightly lower mean $g_{s}$ values in 2013 than in 2012. Despite this, the order of magnitude of the mean $g_{s}$ for the five species has not changed between the two years (Figure 4). 
$T_{\mathrm{s}}$ and related $L_{\mathrm{o}}$ in 2012 and 2013 are presented in Figure 5 (showing days with $T_{\max }>24^{\circ} \mathrm{C}$, when the differences in $T_{\mathrm{s}}$ and $L_{\mathrm{o}}$ were greatest). During the day, particularly between 12:00-16:00 h, plots with Salvia or Stachys had the lowest $T_{\mathrm{s}}$, and $L_{\mathrm{o}}$, whereas plots with Sempervivum or bare substrate had the highest $(p>0.001)$; differences between mean values during that period reached up to $10^{\circ} \mathrm{C}$ and $12 \%$ (or $\sim 65 \mathrm{~W} \mathrm{~m}^{-2}$ ) for $T_{\mathrm{s}}$ and $L_{\mathrm{o}}$, respectively. Values for $T_{\mathrm{s}}$, and related values for $L_{\mathrm{o}}$, of purple Heuchera and Sedum were generally in-between the values of the other four treatments. The differences between mean $T_{s}$ and $L_{o}$ for purple Heuchera or Sedum plots and those with Salvia reached up to $5^{\circ} \mathrm{C}$ and $6 \%$ (or $\sim 30 \mathrm{~W} \mathrm{~m}^{-2}$ ), respectively. In $2012, T_{\mathrm{s}}$ and $L_{\mathrm{o}}$ values for yellow Heuchera plots were similar to those obtained for Salvia and Stachys plots (Figures 5a and c). In contrast, in 2013 after the loss of many of the yellow Heuchera plants, mean $T_{\mathrm{s}}$ and $L_{o}$ in yellow Heuchera plots between 12:00-16:00 $\mathrm{h}$ were up by $4^{\circ} \mathrm{C}$ and $5 \%$ (or $\sim 25 \mathrm{~W} \mathrm{~m}^{-2}$ ), respectively, compared to plots with Salvia and Stachys (Figures 5b and d).

Between 20:00-24:00 h, differences in $T_{\mathrm{s}}$ and $L_{o}$ among treatments, while statistically significant in 2013 ( $\mathrm{p}<0.001$, data not shown), were within $2^{\circ} \mathrm{C}$ or $\sim 10 \mathrm{~W} \mathrm{~m}^{-2}$. As expected, as a result of a lack of short-wave radiation and transpiration during night-time, $T_{s}$ and $L_{o}$ differences between the species were much smaller than during the day. Similar behaviour should be observed for these plants if they were installed on green roofs.

\subsection{Energy balance}

Differences in $R_{\mathrm{n}}$ between treatments were generally less pronounced than the $L_{\mathrm{o}}$ differences. This was due to the small $\alpha$ differences between most plant treatments (Table 3), which resulted in small differences in $S_{\mathrm{o}}$ (data not shown), that counterbalanced the $L_{\mathrm{o}}$ differences. In $2012, R_{\mathrm{n}}$ differences between treatments were not significant ( $\mathrm{p}=0.137$, Figure $6 a$ ). In contrast, in $2013, R_{\mathrm{n}}$ differences were larger between 11:00-15:00 h, with Sempervivum plots having significantly lower mean $R_{\mathrm{n}}$ (11\%) than plots with Stachys and Sedum (p<0.001, Figure 6b). 
363 Despite clear differences between most curves being visible in Figs 6c and 6d, treatments had no overall significant effect on $H$ between 11:00-15:00 h in 2012 (p=0.308, Figure 6c). However, $H$ differences were statistically significant in 2013 ( $\mathrm{p}<0.001$, Figure 6d). Stachys and Salvia had lowest $H$ values during daylight hours, whereas Sempervivum and purple Heuchera had the highest.

\subsubsection{Substrate heat flux $(G)$ and substrate insulation potential}

Between 11:00-15:00 h, $G$ was significantly different between treatments for both years $(\mathrm{p}<0.001$,

Figures 6e and f). Greatest $G$ values were associated with the bare substrate. During 2013 (Figure 6f), the plots with yellow Heuchera, Sempervivum and Sedum had high daytime G, in comparison to plots covered by other canopies. Therefore, in terms of substrate insulation potential, which we defined as the reduction in (surface) ground heat flux by vegetation cover compared to bare substrate, Heuchera, Sempervivum and Sedum had the lowest potential and the other (non-succulent) species the highest.

\subsubsection{Latent heat flux (LE)}

Despite noticeable differences in $L E$ being apparent for a number of treatments between 11:00-15:00 $\mathrm{h}$ in 2012 ( $\mathrm{p}=0.071$, Figure $6 \mathrm{~g}$ ), they were only statistically significant in 2013 ( $\mathrm{p}<0.001$, Figure $6 \mathrm{~h}$ ). This is largely caused by the fact that these curves are based on hourly averages for 10 (year 2012) and 9 (year 2013) days, respectively, so that there will be a relatively large standard deviation (not shown in plots, but influencing the p-values) for each hour, for each treatment. In 2013 in particular, the overall differences in $H$ and $G$ between treatments led to Salvia and Stachys plots having a significantly greater $L E$ (as derived from Eq. 10) than plots with Sempervivum, bare substrate and both Heucheras.

\subsubsection{Overall ranking in daytime energy fluxes}

385 For the most part, differences between treatments tended to be more significant in 2013, reflecting 
Heuchera, where the winter deaths of plants increased the proportion of bare substrate in the plots, with subsequent effects on the plots' thermodynamic behaviour.

Overall, Salvia and Stachys had proportionally low values of $H$ and $G$; and conversely, high values of $L E$. The opposite was true for bare substrate and Sempervivum. As a consequence, the partitioning of $R_{\mathrm{n}}$ into the different heat fluxes differed between treatments. In 2013, for example, the amount of $R_{\mathrm{n}}$ used for $H, G$ and $L E$ between 11:00-15:00 h in Salvia plots planted in 2012 was respectively on average $0 \%, 3 \%$ and $96 \%$ whilst for Sempervivum plots, those percentages were respectively $25 \%$, $18 \%$ and $57 \%$ (Table 4). The percentage of $R_{\mathrm{n}}$ allocated to each of the heat fluxes was intermediate in Sedum and Heuchera plots. Although plots with purple Heuchera had similar $H$ values to those with Sempervivum, purple Heuchera plots had one of the lowest diurnal $G$ in 2013. In the second year, purple Heuchera plots had on average a $\sim 65 \mathrm{~W} \mathrm{~m}^{-2}$ reduction in $G$, compared to Sempervivum plots (Figure 6f). Consequently, in 2013, the amount of $R_{\mathrm{n}}$ used for $G$ in plots with purple Heuchera was on average $15 \%$ lower than in those with Sempervivum, and so in purple Heuchera plots, this extra amount of energy received was instead mainly released as $L E$ (Table 4). In 2012, yellow Heuchera plots showed some of the lowest $H$ and $G$ and highest $L E$ between 11:0015:00 h, data similar to Salvia and Stachys (Figures 6c, e, g and Table 4). However, in 2013, due to plant death, yellow Heuchera plots had on average $\sim 65 \mathrm{~W} \mathrm{~m}^{-2}$ greater $H$ and $G$ and $\sim 130 \mathrm{~W} \mathrm{~m}^{-2}$ lower $L E$ than plots with Salvia planted in 2012 (Figures 6d,f,h). Therefore, in 2013 the percentage of $R_{\mathrm{n}}$ used for $H, G$ and $L E$ in yellow Heuchera plots differed on average by $+14 \%,+15 \%$ and $-29 \%$, respectively, from the percentages allocated for $H, G$ and $L E$ in plots with Salvia (Table 4). Sedum plots, on the other hand, had in both years $H$ and $L E$ values that were in-between those calculated for Salvia and Stachys and for Sempervivum and purple Heuchera. However, G values in Sedum plots were closer to those derived for Sempervivum plots than for Salvia and Stachys plots (Figures 6e and f). For example, in 2013, $G$ between 11:00-15:00 h was on average up to $\sim 45 \mathrm{~W} \mathrm{~m}^{-2}$ greater in Sedum plots than in Salvia plots. This contributed to a 9\% increase in the amount of $R_{\mathrm{n}}$ used for $G$ in plots with Sedum, compared to those with Salvia planted in 2012. Accordingly, the energy 
used by Sedum plots for $L E$ was reduced on average by $20 \%$, compared to Salvia plots in that year

414 (Table 4).

\subsubsection{Overall ranking in night-time energy fluxes}

At night, (20:00-24:00 h), there were no significant treatment differences in $L E$ ( $>00.152$, data not shown), and the absolute differences in $R_{\mathrm{n}}, H$ and $G$, although significant ( $<<0.001$, data not shown) were lower than those shown during the day. For nights with $T_{\min }>12^{\circ} \mathrm{C}$, most vegetated plots, except those with Sempervivum and yellow Heuchera (in 2013), were gaining more $H$ than plots with bare substrate. Furthermore, as expected, at night the upward $G$ (i.e. heat loss) for bare substrate was significantly higher than the $G$ calculated for plots that were completely covered by canopies (hence excluding yellow Heuchera in 2013). Average differences in $H$ and $G$ between vegetated plots and bare substrate plots from 20:00-24:00 h reached $\sim 25 \mathrm{~W} \mathrm{~m}^{-2}$ and $\sim 45 \mathrm{~W} \mathrm{~m}^{-2}$, respectively. Average differences in $H$ and $G$ between vegetated plots alone within the same period were smaller: $\sim 20 \mathrm{~W} \mathrm{~m}^{-2}$ and $\sim 30 \mathrm{~W} \mathrm{~m}^{-2}$, respectively.

[Insert Figure 6 and Table 4]

\section{Discussion}

Previous studies suggest that by extending the area covered by irrigated green roofs within a city, local daytime $L E$ in the summer can be increased. Consequently, there is a reduction in both the heat that is absorbed/stored within buildings and the heat that is returned to the atmosphere (as sensible heat and long-wave radiation) $[41,42]$ and hence, local air temperatures are lower. Thus, the presence of rooftop vegetation provides important air temperature reduction and building insulation during summer. Despite this study not being conducted at roof top level and having plots sizes smaller than typical extensive green roofs, the findings are notable in that they demonstrate that certain plants have the potential to offer more environmental cooling and substrate insulation than others. This challenges conventional thinking on the way most green roofs are currently designed, as plants (on extensive and semi-extensive roofs, with shallow occasionally irrigated substrates) are mostly selected for their survival potential and not for their ability to provide valuable ecosystem services. In essence, many 
existing green roofs could be underperforming with regards to insulating against incoming solar

440 radiation, and reducing air temperatures around buildings.

\subsection{Differences in summertime environmental cooling and substrate insulation potential between} treatments during the warmest period of the day

Canopies formed by non-succulent, light-coloured plants with high $g_{s}$ (Figure 3) and high LAI (e.g. Salvia, regardless of its canopy height, and Stachys) showed the greatest potential for daytime environmental cooling. This was evident in the lowest surface temperatures, and related lowest $L_{\mathrm{o}}$ and $H$ (Figure 5 and 6) and in the highest $L E$ values for plots with these species (Figure 6). These canopies also showed the greatest potential to offer more substrate insulation in hot periods, by having the lowest $G$ (Figure 6). In contrast, succulent plants with low $g_{s}$ and extremely thick leaves (e.g. Sempervivum) showed the lowest substrate insulation potential, and offered no environmental cooling service compared to bare substrate. A thin layer of substrate can in itself offer more thermal insulation to roofs than common standard roof materials [43] and has significantly lower daytime surface temperatures than materials such as concrete, gravel or black membrane [11]. As such, the use of plants which offer greater reduction in substrate heat flux, heat-deflecting and evapotranspiration potential than bare substrate is likely to considerably improve the cooling performance of a roof surface compared to conventional roof systems during the summer months. Consequently, if occasional irrigation (even in climates such as that of the UK/northern Europe where summer rainfall is fairly regular) is supplied such that Salvia, Stachys and species with similar traits can thrive on a roof environment, then their (and similar) canopies could be ideal candidates in helping reduce the heat load to buildings and perhaps the negative effects of the UHI at a local scale. Due to the small size of the plots used in this study and a number of other confounding factors, including typical air movement characteristics around the building envelope, the implications of these differences cannot yet be assessed at the building and urban scales. However, this could be a subject for follow-on empirical evaluations, where these data could be used to provide more accurate plant-based parameters within existing urban heat models (see Conclusions). 
The cooling and insulating properties of other canopies (Heuchera and Sedum) were intermediate.

The potential of the yellow-leaved Heuchera to offer the same summertime substrate insulation and environmental cooling as Salvia and Stachys was evident in 2012. This was due to this genotype possessing a high $\alpha$ and moderate LAI and $g_{s}$. This Heuchera cultivar, however, was not as resilient as Salvia and Stachys, suffering tissue damage and die-back during the winter of 2012/2013, so by the summer of 2013 plots were only partially covered. During 2013, plots with yellow Heuchera had therefore higher $L_{0}, H$ and $G$ and lower $L E$ than those plots covered by Salvia and Stachys, with values actually approaching those of bare substrate. Plants that are poorly adapted to harsh conditions should, therefore, be avoided in unprotected spaces such as rooftops, despite having traits that would in theory lead to maximum environmental cooling and substrate insulation in the summer. In contrast, purple Heuchera survived well in all weather conditions in our experiment. Data here suggests that purple-leaved, non-succulent plants could insulate the substrate from external heat to the same extent as Salvia and Stachys. G in purple Heuchera plots was similar to that in Salvia and Stachys plots once plants reached a certain height (Figure 6). This was possibly because an air gap was created between the lower leaves of the canopy and the substrate in 2013 [27], thereby reducing the temperature gradient between leaves, substrate surface and within the substrate, i.e. the driving force for $G$. However, plants with dark-coloured leaves are best avoided as they do not offer additional environmental cooling. Although the $\alpha$ of purple and green leaves was within the same range in this case, the spectral reflectance showed that purple leaves absorbed more visible radiation than others. There is a large amount of energy per quantum in the visible wavelengths [44], hence purple Heuchera leaves were consistently absorbing more energy than green or yellow ones. This contributes to greater warming of purple leaves than other non-succulent leaf types [20]. In highly urbanised regions, the effect that green roofs may have on temperatures of the surrounding environment (air and urban fabric) can become important. Accordingly, cultivars that offer both maximum environmental cooling and minimum substrate warming in the summer should be preferred. Sedum, the most commonly used plants on extensive green roofs, was shown to be less effective than other plants in its environmental cooling and substrate insulation potential, with the other succulent, 
492 Sempervivum, performing even worse. These plants are popular due to their xerophytic traits and an 493 ability to survive on very shallow substrate on green roofs without supplementary irrigation. Not 494 surprisingly, however, their characteristic small leaves, designed to minimise water loss, compromise their suitability where cooling and shading are important. Although often marketed for their ecosystem service potential, the results presented here indicate that, while Sedum offers a small cooling/insulation benefit over bare substrate (and most likely a modestly larger benefit compared to roofing material), they do not perform as well as some other plants. Particularly in terms of substrate insulation potential, Salvia outperformed Sedum, as $G$ was reduced by up to $\sim 45 \mathrm{~W} \mathrm{~m}^{-2}$ in plots with Salvia compared to plots with Sedum. Although these findings need to be confirmed at the building scale, they indicate that plants such as Salvia would be better suited than Sedum carpets to be used in green roofs where reducing the building heat load in the summer is a priority.

4.2. Main plant traits linked to cooling of the surrounding environment and substrate insulation during the day

$L_{\circ}, H$ and $L E$ are dependent on surface temperatures but also influence the surface temperatures themselves. Consequently, those plant traits that contribute most to lowering leaf temperatures during hot periods also play the largest role in reducing the $L_{\mathrm{o}}$ and $H$ and increasing the $L E$ release into their surroundings, hence leading to enhanced environmental cooling. Based on our findings [see also 20], it can be suggested that there are a number of specific traits that are key for the reduction of heat release into the environment. They include high values of $g_{s}$, high LAI, light leaf colour and low values of leaf thickness. Additionally, as shown by this study and by indirect evidence from other studies [e.g. 29], some of these traits also ensure the largest reduction in $G$, and so the highest ability to potentially provide summertime substrate insulation; (i) in particular high LAI, through increased shading, and (ii) high $g_{s}$, by reducing the energy available for $G$, as a result of large $L E$.

\subsection{Differences in night-time cooling/insulation potential between treatments}

516 Although night-time surface temperatures and heat flux differences were less pronounced than during 517 the day, surface temperatures for Salvia, Purple Heuchera and Stachys between 20:00-24:00 h were 
still significantly lower than for bare substrate or Sempervivum. This indicates that the environmental cooling potentially offered by canopies such as Salvia and Stachys during the day may extend to the early night period.

521 In contrast, at night during the summer, bare substrate allowed more heat to be released (Figure 6e and f) from the substrate layer than the majority of vegetated plots. This inevitably suggests that if the canopies studied were covering a rooftop, less heat would escape the building at night under green roof vegetation, leading to reduced regulation of temperatures inside the building during hot nights. However, semi-extensive roofs - for which the plants we studied would be suitable - are more likely to be deployed on commercial buildings, where daytime temperatures are the main issue. We therefore argue that there is an overall summer insulation benefit to using vegetation.

\subsection{Research limitations}

529 The heat fluxes calculated within this study, particularly $L E$ which was derived from other estimations, may be subject to errors linked to the data collection or the assumptions made during the calculations. A potential shortcoming of the results we reported may be linked with the fact that an explicit advective term (i.e. characterized by the horizontal divergence of $H$, when $H$ is negative and large enough that a downward $H$ is produced at the ground during the daytime $[36,45]$ ) was not included in the energy balance calculations. Instead, advection is implicitly embedded in the $L E$ estimation. To test whether the relative differences among the latent fluxes for the different plant species would remain once an advective term was taken into consideration, further calculations were carried out based on the (micro) advection theory and equations provided in [36] (data not shown). Comparisons between both $L E$ estimations revealed some differences in the absolute flux values but not in the ranking of Salvia, Stachys and Sedum (Sempervivum and bare substrate were excluded as we did not have surface resistances required to calculate the advective $L E$ term). Another point to consider is the fact that air will gradually change its properties to achieve a new equilibrium when flowing over a (vegetated) surface, and so non-equilibrium conditions were likely

543 for our small experimental surfaces. Furthermore, small plots such as the ones used here are prone to edge effects [46]. If the air arriving at the edge of the plot is drier and warmer than the air that would 
be in equilibrium with a similarly vegetated plot of sufficient size, then the horizontal transport of heat may overwhelm any local effects of evaporative cooling. Energy exchanges identified in small plots may not therefore be entirely representative of those observed in real life situations [36].

548 Other potential sources of error lay with the measurements themselves. One example is seen in the wind speed measurements, used in the estimation of $H$ via $r_{a}$. Here wind speed values from the University of Reading's registered meteorological station (approx. $600 \mathrm{~m}$ away from the experimental plots) were used, rather than the data from the somewhat less sophisticated weather station at the experimental plots. The University meteorological station is located in a more exposed area than the experimental plots, so although wind speeds at both sites were broadly in agreement, wind speeds at the meteorological station were slightly higher. Any errors due to an overestimation of wind speed were, however, equally applied to all treatments. In addition, any inaccuracies in other measurements due to limited instrument precision may also have resulted in other slight under/overestimations.

557 Errors in the calculations, due to an error in the measurement of variables such as $T_{\mathrm{a}}, L_{\mathrm{i}}$ and $S_{\mathrm{i}}$ should 558 also be similar for all treatments. The errors linked to temperature measurements made with different individual thermocouples attached to leaves or substrate surface and thermistors placed within the substrate layer could indeed have influenced the relative differences in fluxes found, as the temperatures measured by the sensors could have differed by up to $0.3^{\circ} \mathrm{C}$ (based on the identified precision error). However, we suggest that the overall differences in surface temperatures and fluxes between treatments were large enough to indicate that different canopies will have different substrate insulation and environmental cooling ability.

565 We therefore argue that although most limitations we outlined will have had some influence on the absolute flux values, they did not change the relative differences between treatments on which our conclusions are based.

\section{5. Conclusions}

569 Climate change predictions suggest that heat waves will increase in frequency and intensity in the 570 future, so the summertime temperature regulation provided by plants on green roofs, and indeed elsewhere, green walls, street trees etc. [47], will become increasingly valuable. This study indicates 
that different types of plants significantly differ in their cooling and insulation benefits during hot periods, when it is most needed. Our results suggest that plants such as Salvia and Stachys, which possess key traits required for a reduction in $L_{0}, H$ and $G$ and an increase in $L E$ (i.e. have typically high $g_{s}$ when sufficiently watered, high LAI, leaves with light leaf colour and reflective, and thin leaves) may have an important role to play a role in cooling the surrounding environment and improving the daytime thermal insulation of buildings in the summer, and thus should be given more consideration when planning green roof plant communities.

Looking ahead, the implications for the energy consumption of buildings and for the overall temperatures in the urban environment of using the studied plant species on green roofs still need to be assessed. It is well known that typical green roof interventions have the potential to reduce heat entering buildings and reduce the energy used to regulate internal building temperatures in the summer, although recently the unequivocal thermal benefits of green roofs have been challenged, for example by [13]. Notwithstanding, on the basis of our study we hypothesise that plants such as Salvia and Stachys, which offer added substrate insulation potential during the day in the summer compared to typical green roof cover, could lead to a considerable decrease in the heat gained by a building during that period, when covering its roof. An extrapolation of these preliminary findings to total savings in the energy consumed by a building would need to account also for the winter effects, the local climate and the building construction, among other aspects. This hypothesis needs therefore to be confirmed by a broader-scale evaluation. Models such as EnergyPlus have been developed to predict energy consumptions in buildings. These models have been used to test the performance of green roofs based on the parameterisation of substrate and plant characteristics, such as substrate thermal properties, substrate depth, $g_{s}, h$, LAI and $\alpha[13,48]$. Now that we have collected a detailed set of plant parameters for a range of contrasting canopies, we propose that future research could use available models to investigate the level of such savings for buildings under a range of climate conditions. Furthermore, a number of models are available to study the impact of greening on the microclimate within the urban environment (e.g. ENVI-met, [49]) and, using our data, these could be 
used next to assess the green roof area necessary to make a significant impact on air temperatures at a city scale, initially in a temperate climate.

600 Based on the evidence we collected, we argue that new urban planning policies should take much 601 greater consideration of plant choice, when attempting to maximise ecosystem services provision. Not all components of green infrastructure provide the same benefits, and plant genotype choice within this infrastructure, can strongly determine the type and level of benefits provided. This paper deals with green roof scenarios, but we are aware of parallel work on trees which suggests that some species have four times the cooling potential of others [50]. This paper challenges the notion that Sedum and other succulents commonly used on green roofs are able to provide a viable summer cooling and insulating benefit, and suggests that alternative species, with greater functionality, are preferable. This involves providing these new genotypes with adequate 'support' systems (e.g. supplementary irrigation) if that is what is required to ensure effective environmental cooling and substrate insulation in the summer. Our ongoing research is looking into sustainable ways to provide the water required by these more water-demanding plants and the added costs of such installation.

612 Indeed, through more appropriate choice of plants and by extending the scale of plantings, positive 613 impacts at a city scale may be feasible.

\section{Acknowledgements}

615 This study was financially supported by Fundação para a Ciência e a Tecnologia - Portugal (FCT) and 616 Programa Operacional Potencial Humano/Fundo Social Europeu (POPH-QREN/FSE) through the 617 doctoral grant SFRH/BD/69921/2010 to Madalena Vaz Monteiro. During the period of experimental 618 campaigns and related analyses, Anne Verhoef was in receipt of NERC funding on the SWELTER-21 619 project (NE/I006729/1), "Soil Water - Climate Feedbacks in Europe in the $21^{\text {st }}$ Century (SWELTER620 21)". We thank Val Jasper, Dr Mike Dennett, Prof David Midmore, Dr Curtis Wood, Dr Bruce Main, 621 Trevor Pitman, Michael Stroud, Helen Dominick, Julia Wesley, Suvarna Punalekar and Rebeka Šiling 622 for their contributions to this study. 


\section{References}

[1] T.R. Oke, The energetic basis of the urban heat island, Q. J. R. Meteorol. Soc. 108 (1982) 124.

[2] S. Grimmond, Urbanization and global environmental change: local effects of urban warming, Geogr. J. 173 (2007) 83-88.

[3] A.M. Rizwan, L.Y.C. Dennis, C. Liu, A review on the generation, determination and mitigation of Urban Heat Island, J. Environ. Sci. 20 (2008) 120-128.

[4] J.M. Murphy, D.M.H. Sexton, G.J. Jenkins, P.M. Boorman, B.B.B. Booth, C.C. Brown, et al., UK climate projections science report: Climate change projections, Met Office Hadley Centre, Exeter, 2009.

[5] G.A. Meehl, C. Tebaldi, More intense, more frequent, and longer lasting heat waves in the 21st century, Science (80-. ). 305 (2004) 994-997.

[6] S.E. Gill, J.F. Handley, A.R. Ennos, S. Pauleit, Adapting cities for climate change: The role of the green infrastructure, Built Environ. 33 (2007) 115-133.

[7] D.E. Bowler, L. Buyung-Ali, T.M. Knight, A.S. Pullin, Urban greening to cool towns and cities: A systematic review of the empirical evidence, Landsc. Urban Plan. 97 (2010) 147-155.

[8] R.W.F. Cameron, T. Blanuša, J.E. Taylor, A. Salisbury, A.J. Halstead, B. Henricot, et al., The domestic garden - Its contribution to urban green infrastructure, Urban For. Urban Green. 11 (2012) 129-137.

[9] R.W.F. Cameron, T. Blanuša, Green infrastructure and ecosystem services - Is the devil in the detail?, Ann. Bot. (2016) (in press).

[10] L.L.H. Peng, C.Y. Jim, Green-roof effects on neighborhood microclimate and human thermal sensation, Energies. 6 (2013) 598-618.

[11] N.H. Wong, Y. Chen, C.L. Ong, A. Sia, Investigation of thermal benefits of rooftop garden in the tropical environment, Build. Environ. 38 (2003) 261-270.

[12] S. Saiz, C. Kennedy, B. Bass, K. Pressnail, Comparative life cycle assessment of standard and green roofs, Environ. Sci. Technol. 40 (2006) 4312-4316.

[13] S.S. Moody, D.J. Sailor, Development and application of a building energy performance metric for green roof systems, Energy Build. 60 (2013) 262-269.

[14] J.L. Monteith, Evaporation and environment, Symp. Soc. Exp. Biol. 19 (1965) 205-223.

[15] D.M. Gates, Transpiration and energy exchange, Q. Rev. Biol. 41 (1966) 353-364.

[16] T.R. Oke, J.M. Crowther, K.G. McNaughton, J.L. Monteith, B. Gardiner, The micrometeorology of the urban forest [and discussion], Philos. Trans. R. Soc. B Biol. Sci. 324 (1989) 335-349.

[17] R.W.F. Cameron, J.E. Taylor, M.R. Emmett, What's "cool" in the world of green façades? How plant choice influences the cooling properties of green walls, Build. Environ. 73 (2014) 198-207.

[18] E.P. Del Barrio, Analysis of the green roofs cooling potential in buildings, Energy Build. 27 (1998) 179-193.

[19] O.M. Grant, L. Tronina, H.G. Jones, M.M. Chaves, Exploring thermal imaging variables for the detection of stress responses in grapevine under different irrigation regimes., J. Exp. Bot. 58 (2007) 815-825.

[20] M. Vaz Monteiro, T. Blanuša, A. Verhoef, P. Hadley, R.W.F. Cameron, Relative importance of transpiration rate and leaf morphological traits for the regulation of leaf temperature, Aust. J. Bot. 64 (2016) 32-44.

[21] T. Blanusa, M.M. Vaz Monteiro, F. Fantozzi, E. Vysini, Y. Li, R.W.F. Cameron, Alternatives 
to Sedum on green roofs: Can broad leaf perennial plants offer better "cooling service"?, Build. Environ. 59 (2013) 99-106.

[22] M.A. Monterusso, D.B. Rowe, C.L. Rugh, Establishment and persistence of Sedum spp. and native taxa for green roof applications, HortScience. 40 (2005) 391-396.

[23] A. Nagase, N. Dunnett, Drought tolerance in different vegetation types for extensive green roofs: Effects of watering and diversity, Landsc. Urban Plan. 97 (2010) 318-327.

[24] N. Dunnett, A. Nolan, The effect of substrate depth and supplementary watering on the growth of nine herbaceous perennials in a semi-extensive green roof, Acta Hortic. (2004) 305-309.

[25] O. Schweitzer, E. Erell, Evaluation of the energy performance and irrigation requirements of extensive green roofs in a water-scarce Mediterranean climate, Energy Build. 68 (2014) 2532.

[26] T.C. Liu, G.S. Shyu, W.T. Fang, S.Y. Liu, B.Y. Cheng, Drought tolerance and thermal effect measurements for plants suitable for extensive green roof planting in humid subtropical climates, Energy Build. 47 (2012) 180-188.

[27] C.Y. Jim, Effect of vegetation biomass structure on thermal performance of tropical green roof, Landsc. Ecol. Eng. 8 (2012) 173-187.

[28] M. Zhao, P.C. Tabares-Velasco, J. Srebric, S. Komarneni, R. Berghage, Effects of plant and substrate selection on thermal performance of green roofs during the summer, Build. Environ. 78 (2014) 199-211.

[29] T. Takakura, S. Kitade, E. Goto, Cooling effect of greenery cover over a building, Energy Build. 31 (2000) 1-6.

[30] J. Zhang, F. Tardieu, Relative contribution of apices and mature tissues to ABA synthesis in droughted maize root systems, Plant Cell Physiol. 37 (1996) 598-605.

[31] J. Liang, J. Zhang, G.Y.S. Chan, M.H. Wong, Can differences in root responses to soil drying and compaction explain differences in performance of trees growing on landfill sites?, Tree Physiol. 19 (1999) 619-624.

[32] S. Lu, T. Ren, Y. Gong, R. Horton, An improved model for predicting soil thermal conductivity from water content at room temperature, Soil Sci. Soc. Am. J. 71 (2007) 8-14.

[33] A.J. Brenner, P.G. Jarvis, A heated leaf replica technique for determination of leaf boundary layer conductance in the field, Agric. For. Meteorol. 72 (1995) 261-275.

[34] B.G. Drake, F.B. Salisbury, Aftereffects of low and high temperature pretreatment on leaf resistance, transpiration, and leaf temperature in Xanthium, Plant Physiol. 50 (1972) 572-575.

[35] A. López, F.D. Molina-Aiz, D.L. Valera, A. Peña, Determining the emissivity of the leaves of nine horticultural crops by means of infrared thermography, Sci. Hortic. (Amsterdam). 137 (2012) 49-58.

[36] A. Diaz-Espejo, A. Verhoef, R. Knight, Illustration of micro-scale advection using grid-pattern mini-lysimeters, Agric. For. Meteorol. 129 (2005) 39-52.

[37] J.L. Monteith, G. Szeicz, The radiation balance of bare soil and vegetation, Q. J. R. Meteorol. Soc. 87 (1961) 159-170.

[38] E. Rubio, V. Caselles, C. Badenas, Emissivity measurements of several soils and vegetation types in the 8-14, $\mu \mathrm{m}$ wave band: Analysis of two field methods, Remote Sens. Environ. 59 (1997) 490-521.

[39] S. Liu, G. Hu, L. Lu, D. Mao, Estimation of regional evapotranspiration by TM/ETM+ data over heterogeneous surfaces, Photogramm. Eng. Remote Sens. 73 (2007) 1169-1178.

[40] Y. Andrist-Rangel, A.C. Edwards, S. Hillier, I. Öborn, Long-term K dynamics in organic and conventional mixed cropping systems as related to management and soil properties, Agric. Ecosyst. Environ. 122 (2007) 413-426. 
[41] R.M. Lazzarin, F. Castellotti, F. Busato, Experimental measurements and numerical modelling of a green roof, Energy Build. 37 (2005) 1260-1267.

[42] A. Scherba, D.J. Sailor, T.N. Rosenstiel, C.C. Wamser, Modeling impacts of roof reflectivity, integrated photovoltaic panels and green roof systems on sensible heat flux into the urban environment, Build. Environ. 46 (2011) 2542-2551.

[43] C.Y. Jim, S.W. Tsang, Biophysical properties and thermal performance of an intensive green roof, Build. Environ. 46 (2011) 1263-1274.

[44] J.L. Monteith, M.H. Unsworth, Principles of environmental physics, 3th ed., Elsevier Inc., Amsterdam, 2008.

[45] K.G. McNaughton, P.G. Jarvis, Predicting effects of vegetation changes on transpiration and evaporation, in: T.T. Kozlowski (Ed.), Water Deficits Plant Growth, Vol. VII, Academic Press, New York, 1983: pp. 1-47.

[46] T.R. Oke, Boundary layer climates, 2nd ed., Methuen \& Co. Ltd, London, UK, 1987.

[47] R.W.F. Cameron, J.D. Hitchmough, Environmental horticulture: Science and management of green landscapes, CAB International, Boston, MA, 2016.

[48] D.J. Sailor, A green roof model for building energy simulation programs, Energy Build. 40 (2008) 1466-1478.

[49] E. Ng, L. Chen, Y. Wang, C. Yuan, A study on the cooling effects of greening in a highdensity city: An experience from Hong Kong, Build. Environ. 47 (2012) 256-271.

[50] M.A. Rahman, D. Armson, A.R. Ennos, A comparison of the growth and cooling effectiveness of five commonly planted urban tree species, Urban Ecosyst. 18 (2015) 371-389. 
Figure 1. Photographs of plant canopies used in the experiment, taken in the early summer of 2012. A.

Heuchera 'Obsidian', B. Heuchera 'Electra', C. Salvia officinalis 'Berggarten', D. Stachys byzantina, E. Sempervivum 'Reinhard' and F. Sedum mix.

Figure 2. Schematic representation exemplifying where measurements were made within a plot.

Figure 3. Mean spectral reflectance within the short-wave spectrum for all treatments analysed in 2012, measured during a day in August with $T_{\max }=18^{\circ} \mathrm{C}$.

Figure 4. Mean leaf stomatal conductance $\left(g_{s}\right)$ for all treatments measured; $g_{s}$ is the average of thirty mean $g_{s}$ values per treatment in 2012 (degrees of freedom $($ d.f. $)=149$ ) and twelve $g_{s}$ values per treatment (or eight for Heuchera yellow) in 2013 (d.f. = 67). LSDs are shown at the top of the figure.

Figure 5. Mean diurnal cycle of estimated surface temperature $\left(T_{\mathrm{s}}\right)$ and outgoing long-wave radiation $\left(L_{\mathrm{o}}\right)$ for treatments evaluated in 2012 and 2013. Data presented are a mean of 10 days with $T_{\max }>24^{\circ} \mathrm{C}$. LSDs associated with the REML analysis for the periods delimited by the vertical lines were: a. 4.19 and $b$. $2.81^{\circ} \mathrm{C}$, c. 25.84 and d. $17.07 \mathrm{~W} \mathrm{~m}^{-2}$.

Figure 6. Mean diurnal cycle of estimated net radiation $\left(R_{\mathrm{n}}\right)$ sensible heat flux $(H)$, substrate heat flux $(G)$ and latent heat flux $(L E)$ for treatments evaluated in 2012 and 2013. Data presented are a mean of 10 days (2012) and 9 days (2013) with $T_{\max }>24^{\circ} \mathrm{C}$. LSDs associated with the REML analysis for the periods delimited by the vertical lines were: a. 32.34, b. 18.20, c. 80.28, d. 45.40, e. 55.42, f. 53.64, g. 124.66 and h. $77.24 \mathrm{~W} \mathrm{~m}^{-2}$. 
Nomenclature list and Tables

\section{Nomenclature}

ANOVA analysis of variance

$C_{\mathrm{p}} \quad$ air specific heat $\left(1010 \mathrm{~J} \mathrm{~kg}^{-1} \mathrm{~K}^{-1}\right)$

$d \quad$ zero plane displacement height (m)

$G \quad$ substrate heat flux $\left(\mathrm{W} \mathrm{m}^{-2}\right)$

$g_{s} \quad$ leaf stomatal conductance to water

vapour $\left(\mathrm{mmol} \mathrm{m} \mathrm{m}^{-2} \mathrm{~s}^{-1}\right)$

$H \quad$ sensible heat flux $\left(\mathrm{W} \mathrm{m}^{-2}\right)$

$h \quad$ surface height (m)

$k \quad$ von Karman's constant (0.41)

LAI leaf area index

$L E \quad$ latent heat flux $\left(\mathrm{W} \mathrm{m}^{-2}\right)$

$L_{\mathrm{i}} \quad$ incoming long-wave radiation $\left(\mathrm{W} \mathrm{m}^{-2}\right)$

$L_{\mathrm{o}} \quad$ outgoing long-wave radiation $\left(\mathrm{W} \mathrm{m}^{-2}\right)$

LSD least significant difference

$r_{\mathrm{a}} \quad$ aerodynamic resistance $\left(\mathrm{s} \mathrm{m}^{-1}\right)$

REML residual maximum likelihood

$R_{\mathrm{n}} \quad$ net radiation $\left(\mathrm{W} \mathrm{m}^{-2}\right)$

$S_{\mathrm{i}} \quad$ incoming short-wave radiation $\left(\mathrm{W} \mathrm{m}^{-2}\right)$

$S_{\mathrm{o}} \quad$ outgoing short-wave radiation $\left(\mathrm{W} \mathrm{m}^{-2}\right)$

SMC substrate moisture content $\left(\mathrm{m}^{3} \mathrm{~m}^{-3}\right)$

$T \quad$ substrate temperature $\left({ }^{\circ} \mathrm{C}\right)$

$T_{\mathrm{a}} \quad$ air temperature at $2 \mathrm{~m}\left({ }^{\circ} \mathrm{C}\right)$ 
$T_{\max } \quad$ maximum air temperature $\left({ }^{\circ} \mathrm{C}\right)$

$T_{\min } \quad$ minimum air temperature $\left({ }^{\circ} \mathrm{C}\right)$

$T_{\mathrm{s}} \quad$ leaf/substrate surface temperature $\left({ }^{\circ} \mathrm{C}\right)$

$U_{\mathrm{z}} \quad$ wind speed at $2 \mathrm{~m}\left(\mathrm{~m} \mathrm{~s}^{-1}\right)$

$z \quad$ height/depth of sensors

$z_{\text {oh }} \quad$ surface roughness length for heat and vapour transfer $(\mathrm{m})$

zom surface roughness length for momentum transfer (m)

\section{Greek symbols}

$\alpha \quad$ albedo

$\varepsilon \quad$ surface emissivity

$\lambda \quad$ substrate thermal conductivity $\left(\mathrm{W} \mathrm{m}^{-1} \mathrm{~K}^{-1}\right)$

$\sigma \quad$ Stefan-Boltzmann constant $\left(5.67 \times 10^{-8} \mathrm{~W} \mathrm{~m}^{-2} \mathrm{~K}^{-4}\right)$

$\rho_{\mathrm{a}} \quad$ air density $\left(1.2 \mathrm{~kg} \mathrm{~m}^{-3}\right)$ 
Table 1. Detail of the methodology used while monitoring environmental conditions and surface and substrate temperatures.

\begin{tabular}{|c|c|c|c|}
\hline Type of measurement & Position & Equipment & Number of sensors \\
\hline $\begin{array}{l}\text { Ambient air temperature } \\
\left(T_{\mathrm{a}}\right) \text { and humidity }\end{array}$ & $2 \mathrm{~m}$ from ground & $\begin{array}{c}\text { Screened RHT2n } \\
\text { sensor (Delta-T } \\
\text { Devices Ltd., } \\
\text { Cambridge, UK) }\end{array}$ & 1 \\
\hline $\begin{array}{l}\text { Incoming short-wave } \\
\text { radiation }\left(S_{\mathrm{i}}\right)\end{array}$ & $0.5 \mathrm{~m}$ from ground & $\begin{array}{c}\text { Pyranometer SKS } \\
1110 \text { (Skye } \\
\text { Instruments Ltd., } \\
\text { Llandrindod Wells, } \\
\text { UK) }\end{array}$ & 1 \\
\hline Surface temperature $\left(T_{\mathrm{s}}\right)$ & $\begin{array}{l}\text { Leaf temperature: on the } \\
\text { underside of the leaf. } \\
\text { Bare substrate } \\
\text { temperature: } 0.005 \mathrm{~m} \\
\text { below the surface }\end{array}$ & $\begin{array}{l}\text { Copper-constantan } \\
\text { thermocouples ( } \mathrm{T} \\
\text { fine PTFE insulated } \\
\text { twin twisted wires, } \\
\text { in house } \\
\text { construction) }\end{array}$ & 2 per plot \\
\hline $\begin{array}{l}\text { Substrate temperature } \\
\qquad(T)\end{array}$ & $\begin{array}{l}\text { At } 0.01 \mathrm{~m} \text { and } 0.06 \mathrm{~m} \\
\text { below the substrate } \\
\text { surface }\end{array}$ & $\begin{array}{l}\text { Thermistors (Fenwal } \\
\text { UUA32J2, in house } \\
\text { construction) }\end{array}$ & 2 per plot \\
\hline
\end{tabular}


Table 2. Information on the methodology used to occasionally measure various plant and substrate parameters/variables.

\begin{tabular}{|c|c|c|c|}
\hline $\begin{array}{c}\text { Type of } \\
\text { measurement }\end{array}$ & Equipment & Frequency & Method applied \\
\hline $\begin{array}{l}\text { Substrate moisture } \\
\text { content (SMC) }\end{array}$ & $\begin{array}{l}\text { SM200 probe attached to } \\
\text { a HH2 Moisture Meter } \\
\text { (Delta-T Devices, } \\
\text { Cambridge, UK) }\end{array}$ & $\begin{array}{l}\text { Daily, once (or twice } \\
\text { when plots were } \\
\text { irrigated) }\end{array}$ & 4 measurements per plot \\
\hline $\begin{array}{l}\text { Leaf stomatal } \\
\text { conductance to } \\
\text { water vapour }\left(g_{s}\right) \text { of } \\
\text { non-succulent } \\
\text { leaves and leaves of } \\
\text { Sedum spurium } \\
\text { (with flat leaves) }\end{array}$ & $\begin{array}{c}\text { LCi infra-red gas } \\
\text { analyser with a broad } \\
\text { leaf chamber (ADC } \\
\text { Bioscientific Ltd., } \\
\text { Hoddesdon, UK). } \\
\text { Ambient } \mathrm{CO}_{2} \\
\text { concentration was } 375 \pm \\
10 \mathrm{~mm}^{3} \mathrm{dm}^{-3}\end{array}$ & $\begin{array}{l}30 \text { times in } 2012 \text { and } \\
12 \text { times in } 2013 \text { (or } \\
8 \text { for yellow } \\
\text { Heuchera, due to a } \\
\text { reduction of leaves } \\
\text { compared to 2012) }\end{array}$ & $\begin{array}{c}10 \text { leaves per treatment, } \\
\text { on each sampling } \\
\text { occasion. Between } \\
10: 00-17: 00 \mathrm{~h}\end{array}$ \\
\hline Albedo $(\alpha)$ & $\begin{array}{l}\text { Kipp \& Zonen CNR4 } \\
\text { radiometer (Campbell } \\
\text { Scientific Ltd., } \\
\text { Shepshed, UK), } \\
\text { positioned } 0.1 \mathrm{~m} \text { above } \\
\text { the surface (field of view } \\
\text { of } 180^{\circ} \text { ) }\end{array}$ & $\begin{array}{l}\text { Three cloudless days } \\
\text { in each summer }\end{array}$ & $\begin{array}{c}\text { Measurements recorded } \\
\text { every minute, for approx. } \\
20 \text { minutes, for each } \\
\text { treatment. Between } \\
\text { 10:00-16:00 h }\end{array}$ \\
\hline $\begin{array}{l}\text { Spectral reflectance } \\
(400 \text { and } 1250 \mathrm{~nm})\end{array}$ & $\begin{array}{c}\text { GER } 3700 \\
\text { spectroradiometer with } \\
\text { fibre optic lens, with } \\
\text { field of view } 10^{\circ} \\
\text { (Geophysical and } \\
\text { Environmental Research } \\
\text { Corp., Millbrook, USA), } \\
\text { positioned } 0.5 \mathrm{~m} \text { above } \\
\text { the ground }\end{array}$ & Once in 2012 & $\begin{array}{l}10 \text { measurements per } \\
\text { treatment, around noon }\end{array}$ \\
\hline $\begin{array}{l}\text { Leaf area index } \\
\text { (LAI) }\end{array}$ & $\begin{array}{l}\text { Leaf area meter (Delta-T } \\
\text { Devices, Cambridge, } \\
\text { UK) }\end{array}$ & $\begin{array}{l}\text { Beginning and end of } \\
\text { experiment, each } \\
\text { summer }\end{array}$ & $\begin{array}{l}\text { Leaves collected within a } \\
\text { square frame }(0.15 \times 0.15 \\
\mathrm{m}) \text { in each plot }\end{array}$ \\
\hline Canopy height $(h)$ & Tape measure & $\begin{array}{l}\text { Once half-way of } \\
\text { both experiments }\end{array}$ & $\begin{array}{l}\text { In the centre of each plot, } \\
\text { from substrate to the tip } \\
\text { of the highest leaf }\end{array}$ \\
\hline
\end{tabular}


Table 3. Mean values of albedo $(\alpha)$, leaf area index (LAI) and height $(h)$ for all the treatments evaluated in 2012 and 2013. The standard errors associated with $\alpha$ and LAI means are also presented.

\begin{tabular}{|c|c|c|c|c|c|c|}
\hline \multirow{2}{*}{ Treatments } & \multicolumn{2}{|c|}{$\alpha$} & \multicolumn{2}{|c|}{ LAI } & \multicolumn{2}{|c|}{$h(\mathrm{~m})$} \\
\hline & 2012 & 2013 & 2012 & 2013 & 2012 & 2013 \\
\hline Bare substrate & $0.09 \pm 0.003$ & $0.13 \pm 0.001$ & & & & \\
\hline $\begin{array}{c}\text { Salvia } \\
\text { (planted 2012) }\end{array}$ & $0.21 \pm 0.001$ & $0.23 \pm 0.001$ & $5.5 \pm 0.21$ & $5.6 \pm 0.33$ & 0.35 & 0.60 \\
\hline $\begin{array}{c}\text { Salvia } \\
\text { (planted 2013) }\end{array}$ & & $0.22 \pm 0.002$ & & $5.1 \pm 0.31$ & & 0.25 \\
\hline Stachys & $0.20 \pm 0.001$ & $0.19 \pm 0.001$ & $5.5 \pm 0.12$ & $3.0 \pm 0.27$ & 0.25 & 0.50 \\
\hline $\begin{array}{l}\text { Heuchera } \\
\text { yellow }\end{array}$ & $0.27 \pm 0.001$ & $0.14 \pm 0.003$ & $4.5 \pm 0.45$ & $0.7 \pm 0.21$ & 0.18 & 0.12 \\
\hline $\begin{array}{l}\text { Heuchera } \\
\text { purple }\end{array}$ & $0.20 \pm 0.002$ & $0.20 \pm 0.002$ & $5.5 \pm 0.25$ & $5.1 \pm 0.19$ & 0.20 & 0.30 \\
\hline Sedum & $0.19 \pm 0.001$ & $0.17 \pm 0.001$ & $3.0 \pm 0.32$ & $2.6 \pm 0.23$ & 0.10 & 0.15 \\
\hline Sempervivum & $0.14 \pm 0.001$ & $0.17 \pm 0.001$ & $2.6 \pm 0.17$ & $3.9 \pm 0.03$ & 0.05 & 0.05 \\
\hline
\end{tabular}


Table 4. Mean percentage of net radiation $\left(R_{n}\right)$ received by each treatment allocated to the sensible $(H)$, substrate $(G)$ and latent $(L E)$ heat fluxes. Mean percentages were calculated based on estimated mean absolute $R_{n}, H, G$ and $L E$ values for the period between 11:00-15:00 $\mathrm{h}$ for 10 days in 2012 and 9 days in 2013, all with $T_{\max }>24^{\circ} \mathrm{C}$.

\begin{tabular}{rcccccc}
\hline \multirow{2}{*}{ Treatments } & \multicolumn{3}{c}{$2012-\%$} & $R_{n}$ converted into & \multicolumn{3}{c}{$2013-\%$} & $R_{n}$ converted into \\
& $H$ & $G$ & $L E$ & $H$ & $G$ & $L E$ \\
\hline Bare substrate & 15 & 33 & 51 & 13 & 26 & 62 \\
Salvia (planted 2012) & 7 & 3 & 90 & 0 & 3 & 96 \\
Salvia (planted 2013) & & & & 6 & 3 & 91 \\
Stachys & 12 & 2 & 86 & 1 & 6 & 93 \\
Heuchera yellow & 9 & 3 & 88 & 14 & 18 & 68 \\
Heuchera purple & 28 & 10 & 62 & 25 & 2 & 73 \\
Sedum & 17 & 11 & 72 & 11 & 13 & 76 \\
Sempervivum & 27 & 11 & 63 & 25 & 18 & 57 \\
\hline
\end{tabular}

